\title{
Validity of Particle-Counting Method Using Laser-Light Scattering for Detecting Platelet Aggregation in Diabetic Patients
}

\author{
Hiromichi Nakadate Non-member (Graduate School of Science and Technology, Keio University) \\ Eiichi Sekizuka Non-member (Internal Medicine, National Hospital Organization, Saitama Hospital) \\ Haruyuki Minamitani Member (Graduate School of Science and Technology, Keio University)
}

Keywords : light scattering, particle counting method, platelet aggregation, diabetes

Today, our population of diabetic patients and diabetic patients-to-be is increasing year by year, and diabetic thrombotic complications such as myocardial infarction, stroke, and retinopathy have accordingly become social issues. Chronic hyperglycemia in diabetes causes various hemorheological abnormalities. One of these abnormalities is platelet hyperaggregation, which is a key marker of diabetic thrombotic complications. Therefore, the early detection of platelet hyperaggregation is of the utmost importance if we are to understand the pathogenesis of diabetic thrombotic complications and prevent their development. Among the methodologies for measuring platelet aggregation, a particle-counting method that uses laser-light scattering has recently been developed. Although several studies have used this method to investigate platelet hyperaggregation in diabetic patients, aggregation in some diabetic patients cannot be differentiated from that in healthy controls by the established analytical approach. Hence we aimed to study the validity of a new analytical approach that reflected the phase from platelet activation to the formation of small platelet aggregates. We hoped that this new approach would enable us to use the particle-counting method with laser-light scattering to measure platelet aggregation in healthy controls and in diabetic patients without complications.

We used a laser-light scattering particle analyzer (LSPA), in which platelet-rich plasma in a glass cuvette was irradiated with a laser beam with a wavelength of $675 \mathrm{~nm}$ and side-scattered light from platelet aggregates was detected. The size and number of platelet aggregates were then evaluated from the detected scattered light intensity (SLI). The glass cuvette was kept at $37 \pm 0.5{ }^{\circ} \mathrm{C}$, and platelet-rich plasma (PRP) was mixed by a stirrer during the experiments. We measured spontaneous platelet aggregation and agonist (adenosine diphosphate (ADP), epinephrine, or collagen)-induced platelet aggregation for $10 \mathrm{~min}$ by using LSPA. Agonists were added to the PRP 1 min after measurement started. Platelet aggregates were classified as small, medium, and large according to their SLIs. To measure spontaneous platelet aggregation the total SLI from small aggregates over a 10-min period was compared among healthy controls, diabetic patients with $\mathrm{HbA}_{1 \mathrm{c}}<6.5 \%$, and diabetics with $\mathrm{HbA}_{1 \mathrm{c}} \geq 6.5 \%$. To measure agonist-induced platelet aggregation the total SLI from small aggregates over a 10-min period (established analytical approach) and that over a 2-min period from 1 to $3 \mathrm{~min}$ after the initiation of measurement (new analytical approach) were compared among healthy controls, diabetic patients with $\mathrm{HbA}_{1 \mathrm{c}}<6.5 \%$, and diabetics with $\mathrm{HbA}_{1 \mathrm{c}} \geq 6.5 \%$. In clinical studies it has been reported that diabetic patients with $\mathrm{HbA}_{1 \mathrm{c}} \geq 6.5 \%$ are at risk of developing diabetic complications.

In the measurement of spontaneous platelet aggregation, platelet aggregation in diabetic patients with $\mathrm{HbA}_{1 \mathrm{c}} \geq 6.5 \%$ was significantly greater than in healthy controls, but there was no significant difference in aggregation rates between healthy controls and diabetic patients with $\mathrm{HbA}_{1 \mathrm{c}}<6.5 \%$. In the measurement of agonist-induced platelet aggregation the results obtained by the established analytical approach did not differ from the above spontaneous platelet aggregation results. However, use of the new analytical approach revealed that platelet aggregation in all diabetic patients was significantly greater than in healthy controls (Table 1).

In summary, neither spontaneous platelet aggregation nor agonist-induced platelet aggregation, as measured by the established analytical approach, could be differentiated between healthy controls and diabetic patients with $\mathrm{HbA}_{1 \mathrm{c}}<6.5 \%$, i.e. patients in the early stages of diabetes. However, agonist-induced platelet aggregation as measured by the new analytical approach could be differentiated between healthy controls and patients with early diabetes. These results suggest that platelet aggregation as detected by the particle-counting method using laser-light scattering could be applied in clinical examinations by our new analytical approach to reflect the period from platelet activation to the formation of small platelet aggregates.

Table 1. ADP-induced aggregation of small platelet aggregates among healthy controls, diabetic patients with $\mathrm{HbA}_{1 \mathrm{c}}<6.5 \%$, and diabetics with $\mathrm{HbA}_{1 \mathrm{c}} \geq 6.5 \%$

\begin{tabular}{|c|c|c|c|}
\hline & \multirow{2}{*}{ Healthy controls $(n=6)$} & \multicolumn{2}{|c|}{ Diabetic patients } \\
\hline & & $\mathrm{HbA}_{1 \mathrm{c}}<6.5 \%(\mathrm{n}=7)$ & $\mathrm{HbA}_{1 \mathrm{c}} \geq 6.5 \%(\mathrm{n}=9)$ \\
\hline Fasting blood sugar [mg/dL] & $82 \pm 10$ & $116 \pm 54^{*}$ & $135 \pm 76^{*}$ \\
\hline $\mathrm{HbA}_{1 \mathrm{c}}[\%]$ & $4.5 \pm 0.4$ & $5.7 \pm 0.4^{*}$ & $7.3 \pm 0.5^{*}$ \\
\hline Total SLI in $10 \min \left[\times 10^{6}\right.$ a.u. $]$ & $22.0 \pm 13.2$ & $31.2 \pm 18.9$ & $64.0 \pm 25.8^{*}$ \\
\hline Total SLI in 2 min after addition of ADP $\left[\times 10^{5}\right.$ a.u. $]$ & $10.6 \pm 10.4$ & $64.4 \pm 48.5^{*}$ & $96.0 \pm 69.0^{*}$ \\
\hline
\end{tabular}

$\mathrm{SLI}=$ scattered light intensity. All data are expressed as means $\pm \mathrm{SD} . * P<0.05$ vs. healthy controls. 


\title{
糖尿病患者におけるレーザ散乱粒子計測法を用いた 血小板凝集能測定の有用性
}

\author{
非会員 中楯 浩康* 非会員 関塚 永一** \\ 正 員 南谷 晴之*
}

\section{Validity of Particle-Counting Method Using Laser-Light Scattering for Detecting Platelet Aggregation in Diabetic Patients}

Hiromichi Nakadate*, Non-member, Eiichi Sekizuka**, Non-member, Haruyuki Minamitani*, Member

\begin{abstract}
We aimed to study the validity of a new analytical approach that reflected the phase from platelet activation to the formation of small platelet aggregates. We hoped that this new approach would enable us to use the particle-counting method with laser-light scattering to measure platelet aggregation in healthy controls and in diabetic patients without complications. We measured agonist-induced platelet aggregation for $10 \mathrm{~min}$. Agonist was added to the platelet-rich plasma $1 \mathrm{~min}$ after measurement started. We compared the total scattered light intensity from small aggregates over a 10-min period (established analytical approach) and that over a 2-min period from 1 to 3 min after measurement started (new analytical approach). Consequently platelet aggregation in diabetics with $\mathrm{HbA}_{1 \mathrm{c}} \geq 6.5 \%$ was significantly greater than in healthy controls by both analytical approaches. However, platelet aggregation in diabetics with $\mathrm{HbA}_{1 \mathrm{c}}<6.5 \%$, i.e. patients in the early stages of diabetes, was significantly greater than in healthy controls only by the new analytical approach, not by the established analytical approach. These results suggest that platelet aggregation as detected by the particle-counting method using laser-light scattering could be applied in clinical examinations by our new analytical approach.
\end{abstract}

キーワード : 散乱光, 粒子計測法, 血小板凝集, 糖尿病

Keywords : light scattering, particle counting method, platelet aggregation, diabetes

\section{1. まえがき}

現在，わが国における糖尿病患者およびその予備軍の人 口は年々増加の一途をたどっており，様々な血管合併症が 社会的な問題となっている。糖尿病における慢性的な高血 糖状態は，2 次的変化として，赤血球変形能の低下や血小板 凝集能の克進, 血液粘度の上昇など様々な血液レオロジー 異常を引き起こす。このような異常が糖尿病性血管合併症 の発症・進展を誘発する機序の多くは毛細血管や細小血管 を有する微小循環の異常に起因するが，その中でも血小板 凝集能の立進は，血管内において病的な血栓の形成を誘発 させるため, 網膜症や心筋梗塞, 脳梗塞などの血栓性合併

* 慶應義塾大学大学院理工学研究科

干223-0061 神奈川県横浜市港北区日吉 3-14-1

Graduate School of Science and Technology, Keio University

3-14-1 Hiyoshi, Kohoku-ku, Yokohama-city, Kanagawa 223-0061

** 国立病院機構埼玉病院内科

干351-0102 埼玉県和光市諏訪 2-1

Internal Medicine, National Hospital Organization Saitama

Hospital

2-1 Suwa, Wako-city, Saitama 351-0102
症に密接に関与している。よって, 糖尿病患者における血 栓性合併症の発症・進展を予防するためにも，早期の血小 板凝集能立進の検知が大変重要である。また, 微小循環レ ベルでの血小板凝集能の六進を検知するためには, 僅かな 血小板の活性化や毛細血管や細小血管で観察されるような 微小な凝集塊を検出する必要がある。現在, 臨床検査の項 目でもある血小板凝集能測定は，1962 年，Born らにより開 発された透過光法による測定が広く応用されている(1) (3)。 血小板凝集能測定とは, 血液から単離した血小板浮遊液に 血小板同士の凝集を惹起する薬剤を添加し, 凝集程度を評 価する検査である。しかし，透過光法においては，透過率 に変化が生じるのが比較的大きな凝集塊が生じてからであ るために, 微小凝集塊の検出精度が低下寸るという欠点が ある ${ }^{(4)}$ (7)。また, 実際の生体内では, 大凝集塊を形成させ るような強い血小板凝集惹起物質が放出されることは少な い事からも, より低濃度の血小板凝集惹起物質により形成 された微小凝集塊の検出精度の向上が求められる。そこで 透過光法の欠点を改善すべく, 散乱粒子計測法を用いた血 
小板凝集能測定が考案された ${ }^{(8)(9)}$ 。現在，散乱粒子計測法を 用いた血小板凝集能測定は研究用途で使われており, 臨床 応用に向けた標準化や適切な評価法は未だ確立されていな い。糖尿病患者における散乱粒子計測法を用いた血小板凝 集能測定はいくつか報告があるが，全ての糖尿病患者にお いて健常者と有意な差が認められているわけではな い(19) (22)。そこで本研究では，同測定法を用いた血小板凝集 能測定の新しい解析法を提案することで, 糖尿病患者にお ける血小板凝集能の古進をより高精度に検出することを目 的とした。

\section{2. 方 法}

\section{〈2・1〉レーザ散乱粒子計測法による血小板凝集能測定}

本研究では，Fig. 1 に示したようなレーザ散乱粒子計測装 置 (laser-light scattering particle analyzer 以下 LSPA)を用いた。 LSPA は, low shear rate で流動する血小板浮遊液にレーザ光 を照射し, 得られる側方散乱光強度から凝集塊の大きさと 数を定量的に評価する。レーザ光には半導体レーザ（波長 $675 \mathrm{~nm} ）$ の近赤外光を用いている。そして集光レンズを用 いて, 照射径約 $40 \mu \mathrm{m}$ 程度にまで絞られ試料に照射される。 試料は, 専用の外径 $7 \mathrm{~mm}$, 高さ $50 \mathrm{~mm}$ の円柱状のガラスキ ユベットに入れて実験を行なう。キュベットはインキュベ 一ターを用いて生体内と条件が等しくなるように $37^{\circ} \mathrm{C} （ \pm$ $\left.0.5^{\circ} \mathrm{C}\right)$ に保温されている。また測定中はキュベット内の金 属スターラーが $1000 \mathrm{rpm}$ で回転しており, 試料を攪挥する。

レーザ光は，多重散乱を避けるため，キュベットの内壁 より約 $1 \mathrm{~mm}$ の近傍に照射され, 2 箇所の測定領域 $(20 \times 60$ $\times 140 \mu \mathrm{m})$ より入射光の光軸に対して $90^{\circ}$ 方向の散乱光を 対物レンズにて集光し，2つのフォトダイオードにより散乱 光強度を電圧として $100 \mu \mathrm{s}$ 毎に検出する。その際, 散乱光 強度は差動増幅器によりバックグラウンドをキャンセルさ

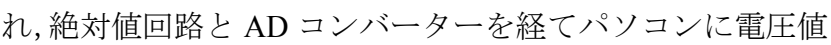
として取得される（Fig. 2)。

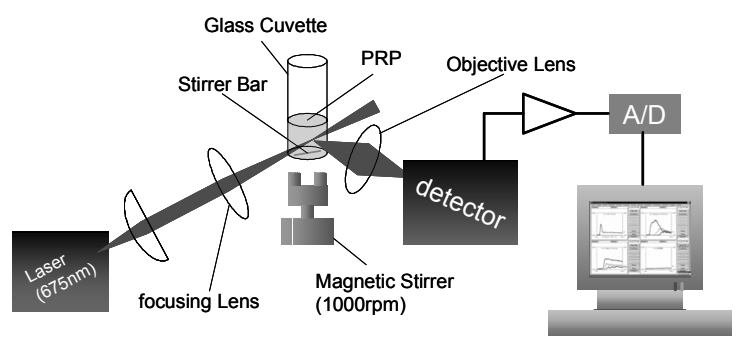

Fig. 1. Diagram of Laser-light scattering particle analyzer

〈2・2〉 データ処理電圧值として取得された散乱光 強度は，1 から 32 の閾值によりレベル分けされ（Fig. 3)， 各閾值における検出回数（Fig. 3 のピーク数）を時系列で解 析可能である（Fig. 4）。閾值 2 から 21 までを小凝集塊（S 領域), 閾值 22 から 27 までを中凝集塊（M 領域）閾值 28 から 31 までを大凝集塊（L 領域）とし, 各領域内で検出さ れた散乱光強度の総和（総散乱光強度）の時系列変化を凝
集曲線として解析可能である (Fig. 5)。ここで, 閾值 $L$ を(1) 式に, S, M, L の各領域の総散乱光強度を(2)式より定義 した。散乱光強度 $I$ は粒子径の 2 乗に比例することから, 閾 值 $L$ は粒子径に対して線形を示し, 検出された凝集塊の大 きさを表す指標となる。よって LSPA を用いた血小板凝集能 測定では, 凝集能は各領域の総散乱光強度で定義され, 凝 集塊の大きさと個数を反映する。なお, 凝集していない単 一血小板からの微弱な散乱光強度（閾值 1 以下）と出力電

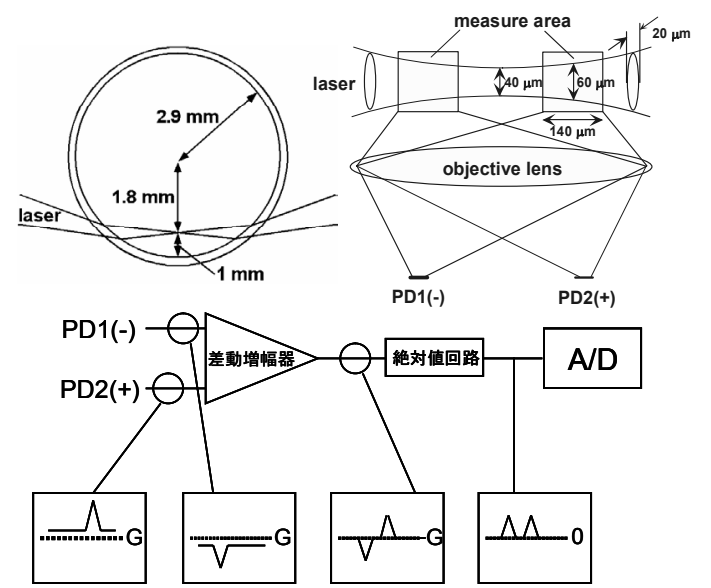

Fig. 2. Detection method of scattered light from platelet aggregates

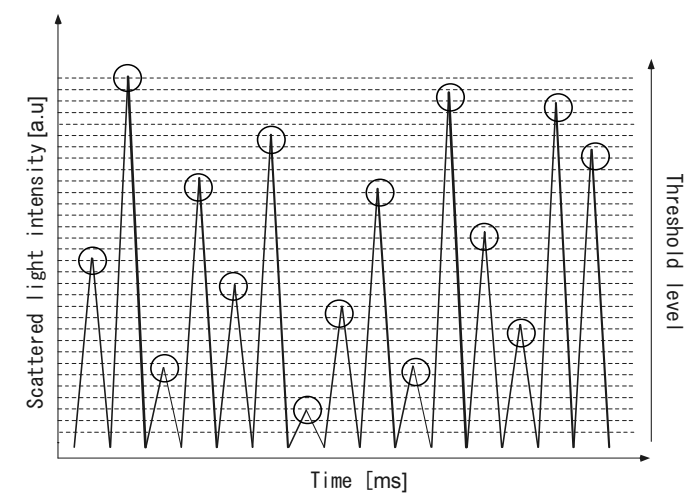

Fig. 3. Image of electronic signal converted from scattered light intensity by LSPA

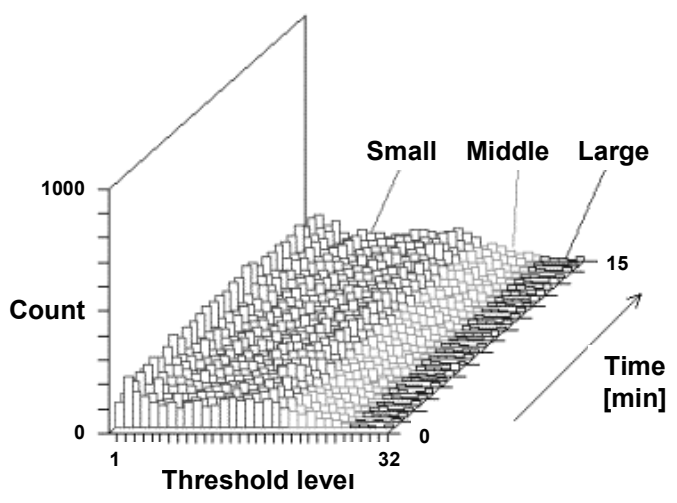

Fig. 4. Real-time analyses of platelet aggregates count by LSPA 
圧が飽和に達した散乱光強度（閾值 32 以上）は解析データ に含めなかった。

$$
L=16.1 \times \log _{10} I-20.6
$$

$L$ : Threshold level $1 \leqq \mathrm{~L} \leqq 32, I$ : Scattered light intensity 各領域の総散乱光強度 $=$ 各領域の閾值 $L($ 散乱光強度 $I)$ $\times$ 検出回数

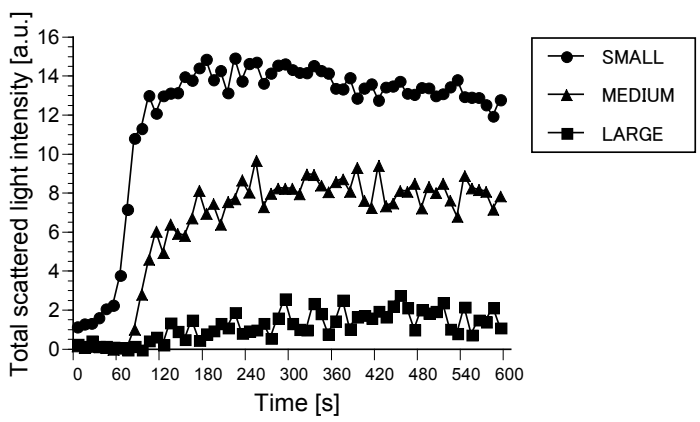

Fig. 5. Real-time platelet aggregation curve by LSPA

\section{〈2·3〉 小凝集塊生成初期における血小板凝集能解析}

健常者および合併症を併発していない糖尿病患者を $\mathrm{HbA}_{1 \mathrm{c}}$ が 6.5\%未満および 6.5\%以上の 2 群に分け，LSPA を 用いて血小板凝集能測定実験を行った。インフォームドコ ンセントの下，薬剤を服用していない健常者および糖尿病 患者から $3.8 \%$ クエン酸採血により採取した血液を $150 \mathrm{~g}$ （g は重力加速度)で 10 分間の遠心分離により PRP (platelet-rich plasma) を，その後さらに $550 \mathrm{~g}$ で 10 分間の遠心分離によ り PPP (platelet-poor plasma) を作成した。実験には，PRPを PPP で約 30 万個 / $\mu \mathrm{l}$ に濃度調整を行った調整 PRP を用い た。測定時間は 10 分間とし，キュベット内のスターラーの 攪找だけで血小板凝集を惹起させる実験（自然凝集）と， 低濃度の血小板凝集惹起物質（終濃度 adenosine diphosphate; ADP $0.5 \mu \mathrm{M}$, Epinephrine $0.3 \mu \mathrm{M}$, Collagen $1.0 \mu \mathrm{g} / \mathrm{mL}$ ） を用い た実験を行った。血小板凝集惹起物質は，測定開始 1 分後 に調整 PRP に添加した。得られた測定データから血小板凝 集能を二通りの解析法で評価した。第一は，測定開始から 10 分間の $\mathrm{S}$ 領域における総散乱光強度を求めた。これは, 小凝集塊生成後の血小板凝集能を表す。第二に，測定開始 1 分後から 3 分後までの 2 分間の $\mathrm{S}$ 領域における総散乱光強 度（自然凝集以外）を求めた。これは，血小板の活性化か ら小凝集塊生成初期の血小板凝集能を表す。 $\langle 2 \cdot 4\rangle$ 統計学的解析 小凝集塊生成初期過程におけ る凝集能解析のデータは平均值 \pm 標準偏差で表し, 健常者 および糖尿病患者の血小板凝集能における有意差検定には Steel 検定を用いた。

\section{3. 結 果}

\section{〈3·1〉健常者および糖尿病患者における自然凝集}

健常者および糖尿病患者におけるキュベット内のスター ラーの攪找だけで血小板凝集を惹起した際に得られた凝集 曲線の典型的な一例を Fig. 6 に示した。健常者においては 小凝集塊の形成はほとんど認められなかったが（Fig. 6 a)）, 糖尿病患者においては, 小凝集塊の形成が明らかに認めら れた患者と (Fig. 6 b)), 健常者と同様, 僅かな形成しか認 められなかった患者（データ未掲載）とが存在した。

健常者， $\mathrm{HbA}_{1 \mathrm{c}}$ が $6.5 \%$ 未満および $6.5 \%$ 以上の糖尿病患者 を対象に，血小板を自然凝集させる条件で，測定開始から 10 分間の S 領域における総散乱光強度を Table 1 に示した。 その結果, 健常者に比し, $\mathrm{HbA}_{1 \mathrm{c}}$ が $6.5 \%$ 以上の糖尿病患者 では 10 分間の総散乱光強度に有意な増加が認められたのに 対し, $6.5 \%$ 未満の糖尿病患者では有意な増加は認められな かった。
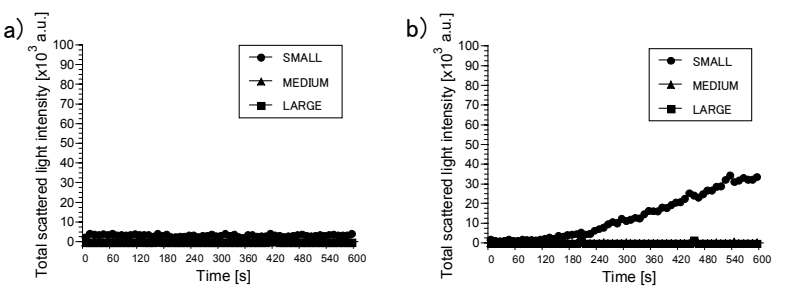

Fig. 6. Typical patterns of spontaneous platelet aggregation curve in a healthy control a) and a diabetic patient b)

〈3・2〉健常者および糖尿病患者における ADP 惹起血小 板凝集健常者および糖尿病患者における ADP 惹起血小 板凝集能測定実験で得られた凝集曲線の典型的な一例を Fig. 7 に示した。凝集曲線は, 小, 中, 大凝集塊から検出さ れた散乱光強度の総和が経時的に変化している状態を表し ている。ADP 惹起においては，健常者では一度小凝集塊（S 領域）が生成した後, 凝集塊が解離する一次凝集が認めら れたのに対し (Fig. 7 a)), 糖尿病患者では, 生成した小凝 集塊が解離しない二次凝集が認められた（Fig. 7 b)）。また， 糖尿病患者では小凝集塊とともに中凝集塊の生成が認めら れた。

Table 1. Spontaneous platelet aggregation of small aggregates among healthy controls, diabetic patients with $\mathrm{HbA}_{1 \mathrm{c}}<6.5 \%$ and diabetics with $\mathrm{HbA}_{1 \mathrm{c}} \geq 6.5 \%$

\begin{tabular}{cccc}
\hline & Healthy controls $(\mathrm{n}=6)$ & \multicolumn{3}{c}{ Diabetic patients } & \multicolumn{3}{c}{$\mathrm{HbA}_{1 \mathrm{c}}<6.5 \%(\mathrm{n}=5)$} & $130 \pm 60$ & $\mathrm{HbA} \mathrm{Ac}_{\mathrm{c}} \geq 6.5 \%(\mathrm{n}=6)$ \\
\hline Fasting blood sugar $[\mathrm{mg} / \mathrm{dL}]$ & $95 \pm 13$ & $136 \pm 69$ & \\
$\mathrm{HbA}_{1 \mathrm{c}}[\%]$ & $4.9 \pm 0.4$ & $5.8 \pm 0.3^{*}$ & $7.3 \pm 0.5^{*}$ \\
Total SLI in $10 \min \left[\times 10^{6}\right.$ a.u. $]$ & $3.5 \pm 2.0$ & $6.5 \pm 3.5$ & $39.0 \pm 31.5^{*}$ \\
\hline
\end{tabular}

$\mathrm{SLI}=$ scattered light intensity. All data are expressed as means $\pm \mathrm{SD} . * \mathrm{P}<0.05$ vs. healthy controls. 
Table 2. ADP-induced platelet aggregation of small aggregates among healthy controls, diabetic patients with $\mathrm{HbA}_{1 \mathrm{c}}<6.5 \%$ and diabetics with $\mathrm{HbA}_{1 \mathrm{c}} \geq 6.5 \%$

\begin{tabular}{cccc}
\hline & Healthy controls $(\mathrm{n}=6)$ & \multicolumn{2}{c}{ Diabetic patients } \\
$\mathrm{HbA}_{1 \mathrm{c}}<6.5 \%(\mathrm{n}=7)$ & $116 \pm 54^{*}$ & $\mathrm{HbA} \geq 6.5 \%(\mathrm{n}=9)$ \\
\hline Fasting blood sugar $[\mathrm{mg} / \mathrm{dL}]$ & $82 \pm 10$ & $5.7 \pm 0.4^{*}$ & $135 \pm 76^{*}$ \\
$\mathrm{HbA}_{1 \mathrm{c}}[\%]$ & $4.5 \pm 0.4$ & $31.2 \pm 18.9$ & $7.3 \pm 0.5^{*}$ \\
Total SLI in $10 \min \left[\times 10^{6}\right.$ a.u. $]$ & $22.0 \pm 13.2$ & $64.0 \pm 25.8^{*}$ & $64.4 \pm 48.5^{*}$ \\
\hline
\end{tabular}

$\mathrm{SLI}=$ scattered light intensity. All data are expressed as means \pm SD. $* \mathrm{P}<0.05$ vs. healthy controls.

健常者, $\mathrm{HbA}_{1 \mathrm{c}}$ が $6.5 \%$ 未満および $6.5 \%$ 以上の糖尿病患者 を対象に, 測定開始から 10 分間の $\mathrm{S}$ 領域における総散乱光 強度, および測定開始 1 分後から 3 分後までの 2 分間の $\mathrm{S}$ 領域における総散乱光強度を Table 2 に示した。その結果, 健常者に比し, $\mathrm{HbA}_{1 \mathrm{c}}$ が $6.5 \%$ 以上の糖尿病患者では 10 分間 と 2 分間の両方で総散乱光強度に有意な増加が認められた。 一方, $6.5 \%$ 未満の糖尿病患者では 10 分間の総散乱光強度に 有意な増加は認められなかったが, 2 分間の総散乱光強度に は有意な増加が認められた。
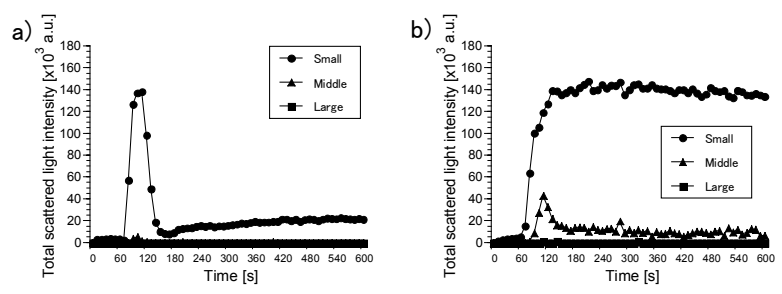

Fig. 7. Typical patterns of ADP induced-platelet aggregation curve in a healthy control a) and a diabetic patient b)

\section{〈3.3〉健常者および糖尿病患者における Epinephrine} 惹起血小板凝集健常者および糖尿病患者における Epinephrine 惹起血小板凝集能測定実験で得られた凝集曲線 の典型的な一例を Fig. 8 に示した。Epinephrine 惹起におい ては，健常者では小凝集塊のみの生成が認められたが（Fig. $8 \mathrm{a})$ ), 糖尿病患者では小, 中凝集塊の生成が認められた (Fig. 8 b))。

健常者, $\mathrm{HbA}_{\mathrm{lc}}$ が 6.5\%未満および 6.5\%以上の糖尿病患者 を対象に, 測定開始から 10 分間の $\mathrm{S}$ 領域における総散乱光 強度および測定開始 1 分後から 3 分後までの 2 分間の $\mathrm{S}$ 領 域における総散乱光強度を Table 3 に示した。その結果, 健 常者に比し, $\mathrm{HbA}_{\mathrm{lc}}$ が $6.5 \%$ 以上の糖尿病患者では 10 分間と 2 分間の両方で総散乱光強度に有意な増加が認められた。一 a) $\overline{\bar{\sigma}}$

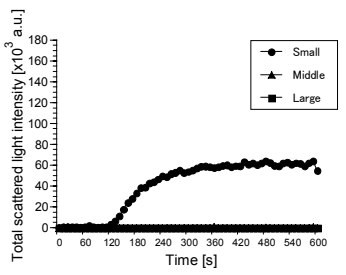

b)

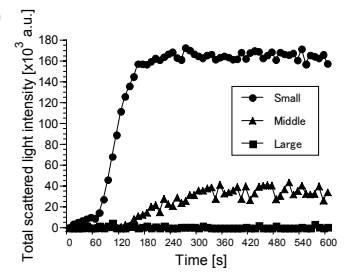

Fig. 8. Typical patterns of epinephrine induced-platelet aggregation curve in a healthy control a) and a diabetic patient b)

方, $6.5 \%$ 未満の糖尿病患者では 10 分間の総散乱光強度に有 意な増加は認められなかったが, 2 分間の総散乱光強度には 有意な増加が認められた。

〈3.4〉健常者および糖尿病患者における Collagen 惹起 血小板凝集健常者および糖尿病患者における Collagen 惹起血小板凝集能測定実験で得られた凝集曲線の典型的な 一例を Fig. 9 に示した。Collagen 惹起においては, 健常者, 糖尿病患者ともに小, 中, 大凝集塊一の生成が経時的に推 移する様子が認められた（Fig. 9 a, b ) )。また, 中凝集塊の 生成においては両者で同程度であるのに対して, 小凝集塊 と大凝集塊の生成においては糖尿病患者で明らかに増大し ていた。

健常者, $\mathrm{HbA}_{1 \mathrm{c}}$ が $6.5 \%$ 未満および $6.5 \%$ 以上の糖尿病患者 を対象に, 測定開始から 10 分間の $\mathrm{S}$ 領域における総散乱光 強度および測定開始 1 分後から 3 分後までの 2 分間の $\mathrm{S}$ 領 域における総散乱光強度を Table 4 に示した。その結果, 健 常者に比し, 糖尿病患者の両群において 10 分間の総散乱光 強度に有意な増加は認められなかったが, 2 分間の総散乱光 強度には有意な増加が認められた。

以上の結果から, 同種同濃度の惹起物質で血小板を刺激 した際, 健常者に比し, 糖尿病患者では血小板凝集能が六

Table 3. Epinephrine-induced platelet aggregation of small aggregates among healthy controls, diabetic patients with $\mathrm{HbA}_{1 \mathrm{c}}<6.5 \%$ and diabetics with $\mathrm{HbA}_{1 \mathrm{c}} \geq 6.5 \%$

\begin{tabular}{|c|c|c|c|}
\hline & \multirow{2}{*}{ Healthy controls $(n=6)$} & \multicolumn{2}{|c|}{ Diabetic patients } \\
\hline & & $\mathrm{HbA}_{1 \mathrm{c}}<6.5 \%(\mathrm{n}=5)$ & $\mathrm{HbA}_{1 \mathrm{c}} \geq 6.5 \%(\mathrm{n}=7)$ \\
\hline Fasting blood sugar $[\mathrm{mg} / \mathrm{dL}]$ & $86 \pm 11$ & $103 \pm 23$ & $138 \pm 64 *$ \\
\hline $\mathrm{HbA}_{1 \mathrm{c}}[\%]$ & $4.3 \pm 0.2$ & $5.7 \pm 0.8^{*}$ & $7.1 \pm 0.4 *$ \\
\hline Total SLI in $10 \min \left[\times 10^{6}\right.$ a.u. $]$ & $21.7 \pm 10.4$ & $37.2 \pm 18.0$ & $53.8 \pm 21.4^{*}$ \\
\hline Total SLI in 2 min after addition of Epinephrine [ $\times 10^{5}$ a.u.] & $2.3 \pm 2.6$ & $60.1 \pm 73.7 *$ & $64.6 \pm 71.2 *$ \\
\hline
\end{tabular}

$\mathrm{SLI}=$ scattered light intensity. All data are expressed as means \pm SD. $* \mathrm{P}<0.05$ vs. healthy controls. 
Table 4. Collagen-induced platelet aggregation of small aggregates among healthy controls, diabetic patients with $\mathrm{HbA}_{1 \mathrm{c}}<6.5 \%$ and diabetics with $\mathrm{HbA}_{1 \mathrm{c}} \geq 6.5 \%$

\begin{tabular}{|c|c|c|c|}
\hline & \multirow{2}{*}{ Healthy controls $(n=5)$} & \multicolumn{2}{|c|}{ Diabetic patients } \\
\hline & & $\mathrm{HbA}_{1 \mathrm{c}}<6.5 \%(\mathrm{n}=6)$ & $\mathrm{HbA}_{1 \mathrm{c}} \geq 6.5 \%(\mathrm{n}=8)$ \\
\hline Fasting blood sugar [mg/dL] & $86 \pm 11$ & $117 \pm 58$ & $113 \pm 22 *$ \\
\hline $\mathrm{HbA}_{1 \mathrm{c}}[\%]$ & $4.2 \pm 0.2$ & $5.4 \pm 0.6^{*}$ & $7.0 \pm 0.3^{*}$ \\
\hline Total SLI in $10 \min \left[\times 10^{6}\right.$ a.u. $]$ & $17.8 \pm 7.3$ & $30.3 \pm 19.8$ & $22.5 \pm 17.7$ \\
\hline Total SLI in 2 min after addition of Collagen [ $\times 10^{5}$ a.u.] & $9.4 \pm 14.4$ & $55.1 \pm 19.3^{*}$ & $34.1 \pm 26.5^{*}$ \\
\hline
\end{tabular}

$\mathrm{SLI}=$ scattered light intensity. All data are expressed as means \pm SD. $* \mathrm{P}<0.05$ vs. healthy controls.

進していることが示された。また，測定開始 1 分後から 3 分後までの 2 分間の $\mathrm{S}$ 領域における総散乱光強度を血小板 凝集能として評価することで, 糖尿病患者における血小板 凝集能の六進をより高精度に検出できることが示された。
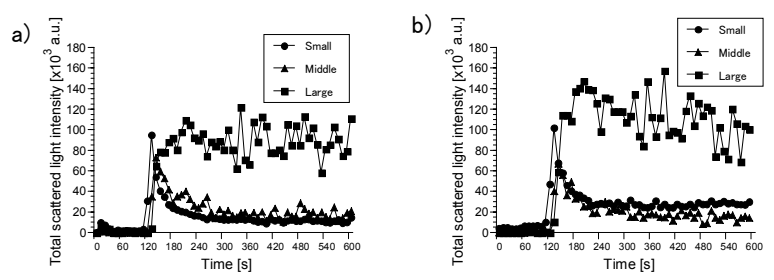

Fig. 9. Typical patterns of collagen induced-platelet aggregation curve in a healthy control a) and a diabetic patient b)

\section{4. 考 察}

本研究では，健常者と合併症を伴わない糖尿病患者にお ける小凝集塊の自然凝集を，散乱光法を用いて検討した。2 型糖尿病患者を対象に厳格な血糖コントロールにより患者 の QOL を劦かす網膜症や腎症, 神経障害といった細小血管 合併症の発症・進展が阻止できるかどうかを 6 年間追跡した Kumamoto Study において, $\mathrm{HbA}_{1 \mathrm{c}}$ が $6.5 \%$ 未満, 食後 2 時間 血糖值が $180 \mathrm{mg} / \mathrm{dL}$ 未満であれば細小血管合併症の出現する 可能性が少ないことが報告されている ${ }^{(12)}$ 。よって我々は, 糖尿病あるいはその予備軍の早期発見，合併症発症の予防 診断を目的に, 糖尿病患者を $\mathrm{HbA}_{1 \mathrm{c}}$ が $6.5 \%$ 未満と $6.5 \%$ 以上 に分け血小板凝集能を測定した。まずキュベット内のスタ ーラーの攪拌だけで惹起した血小板凝集を検討した。その 結果，健常者に比し， $\mathrm{HbA}_{1 \mathrm{c}}$ が $6.5 \%$ 以上の糖尿病患者では 小凝集塊の有意な増加が認められたが, $\mathrm{HbA}_{1 \mathrm{c}}$ が $6.5 \%$ 未満 の糖尿病患者では有意な増加は認められなかった。このこ とは, $\mathrm{HbA}_{1 \mathrm{c}}$ が $6.5 \%$ 未満の糖尿病患者では, 自然凝集をす る患者としない患者が存在することが原因であると考えら れる。先行研究において, 糖尿病患者における自然凝集の 増加は既にいくつか報告されている(19) (21)。Fukuda らは, 健常者に比し糖尿病患者において有意に自然凝集が増加し ていることを報告しているが，糖尿病患者の平均 $\mathrm{HbA}_{1 \mathrm{c}}$ が 7.5\%であり ${ }^{(19)}$, 一概に本結果とは比較し難い。また Iwase らは, 糖尿病が進行することで併発する網膜症, 腎症, 神 経障害の重篤度に伴って自然凝集の有意な増加を報告して いるが，健常者とこれらの合併症を伴わない糖尿病患者と
では自然凝集に有意な差は認められていない(20)。よって, 合併症の併発もなく $\mathrm{HbA}_{1 \mathrm{c}}$ も $6.5 \%$ 未満である糖尿病患者に おいて検討した報告は未だなく, 本実験結果からも自然凝 集のみで糖尿病の初期および合併症併発前の血小板凝集能 の㐫進は検知できないため, 惹起物質による血小板凝集能 測定が必要だと思われる。

次に我々は, 低濃度の血小板凝集惹起物質を用いて検討 を行った。LSPA などの凝集計による in vitro 系の血小板凝 集機序は, 生体内の血栓止血機構とは異なる。血小板は, 通常基石のような円盤状を示しているが，凝集惹起物質の 添加により活性化され, 棘状の偽足を出した球状に形態変 化する。血小板の活性化に伴い, 血小板膜糖タンパクであ る GPIIb/IIIa 複合体が活性化し粘着タンパクの高親和性受容 体に構造を変化させる。血漿中には二量体構造を持つ粘着 タンパクの Fibrinogen が存在するため, 活性化血小板同士を Fibrinogen が GPIIb/IIIa を介して架橋することで可逆的な血 小板凝集が起こる (一次凝集)。そして凝集が惹起されると 血小板の形態変化は促進され, 凝集した血小板の偽足が複 雑に絡み合い, ADP などの濃染顆粒の放出や強い血小板凝 集作用を持つ Thromboxane $\mathrm{A}_{2}\left(\mathrm{TX} \mathrm{A}_{2}\right)$ を産生する。放出さ れた $\mathrm{ADP} や \mathrm{TX} \mathrm{A}_{2}$ は他の血小板を活性化し, 不可逆的な凝 集を六進させる (二次凝集） ${ }^{(13)}$ 。ADP 惹起による血小板凝 集は，血小板膜上の受容体に ADP が結合することにより， 一次凝集を惹起することが報告されている(14)。本実験の ADP 惹起血小板凝集能測定においても, 健常者では小凝集 塊において, 糖尿病患者では中凝集塊において一度凝集塊 が生成した後に凝集塊が解離する一次凝集が認められた。

Epinephrine は, 血小板膜上に存在する $\alpha_{2}$-adrenaline 受容体を 介して血小板凝集を惹起することが知られている(15)。また Epinephrine 自体は血小板凝集惹起物質ではなく, ADP 結合 の親和性を増強させることで凝集を惹起しているという報 告がある(16)。そのため, 本実験の Epinephrine 惹起血小板凝 集能測定で観察された緩やかな凝集反応は, 上述した一次 凝集を経た後, 二次凝集が起こっていると考えられる。 Collagen による血小板活性化は, 血小板膜上の Collagen 受 容体である GPVI との結合により, 刺激がチロシンリン酸化 を介して伝達されると考えられている(17)。また Collagen 惹 起による血小板凝集は, ADP や Epinephrine とは異なり, 一 次凝集を経ずに最初から放出反応を伴う二次凝集を惹起す るという報告がある(18)。本実験の Collagen 惹起血小板凝集 能測定においても, Collagen 添加直後から大凝集塊を惹起す る強い凝集反応が観察された。何れの惹起物質を用いた血 
小板凝集能測定においても，凝集反応のパターンは同様で あるが，健常者に比し，糖尿病患者ではより大きな凝集塊 が生成されており, 糖尿病患者において血小板凝集能の亢 進が示された。糖尿病患者の血小板凝集能六進は, 上述し た凝集機序からも, 糖尿病患者の血小板における Fibrinogen に対する結合の立進 ${ }^{(10)}$ やX $\mathrm{A}_{2}$ 合成立進 ${ }^{(11)}$ が関与している と考えられる。

さらに我々は，健常者， $\mathrm{HbA}_{1 \mathrm{c}}$ が 6.5\%未満および 6.5\%以 上の糖尿病患者を対象に, ADP, Epinephrine, Collagen 惹起 血小板凝集能測定から得られたデータを二通りの解析法で 評価した。第一は, 小凝集塊生成後の血小板凝集能として, 測定開始から 10 分間の $\mathrm{S}$ 領域における総散乱光強度を求め た。第二は，血小板の活性化から小凝集塊生成初期の血小 板凝集能として, 凝集惹起物質を添加した測定開始 1 分後 から 3 分後までの 2 分間の $\mathrm{S}$ 領域における総散乱光強度を 求めた。その結果, $\mathrm{HbA}_{1 \mathrm{c}}$ が $6.5 \%$ 以上の糖尿病患者におい ては, Collagen 惹起を除いて, 10 分間の総散乱光強度およ び血小板凝集惹起物質を添加後 2 分間の総散乱光強度の両 解析法で, 健常者に比し, 小凝集塊の有意な増加が認めら れた。一方, $\mathrm{HbA}_{1 \mathrm{c}}$ が $6.5 \%$ 未満の糖尿病患者においては, 血小板凝集惹起物質を添加後 2 分間の総散乱光強度でのみ 小凝集塊の有意な増加が認められた。この結果は, 従来, 解析されてきた小凝集塊生成後の血小板凝集能を評価する よりも, 今回我々が提案した血小板の活性化から小凝集塊 生成初期の血小板凝集能を評価する方が，より糖尿病患者 における血小板活性化のし易さや血小板凝集の立進度を顕 著に反映するためと考えられる。先行研究においては, Matsuno らが合併症を伴わない糖尿病患者における ADP 惹 起血小板凝集能測定を検討している(22)。Matsuno らは，まず 糖尿病患者を自然凝集する患者としない患者に分け, 各群 を健常者と比較している。その結果, 自然凝集する糖尿病 患者では健常者に比べ有意に小凝集塊が増加しているのに 対し, 自然凝集しない患者は有意な差は認められなかった。 また, 両糖尿病患者群の $\mathrm{HbA}_{1 \mathrm{c}}$ は自然凝集する群で平均 $7.2 \%$, 自然凝集しない群で $6.7 \%$ あった。この結果は，本 実験結果を支持するものであり, 合併症を伴わなく, $\mathrm{HbA}_{1 \mathrm{c}}$ が低い糖尿病患者では, 健常者に比し, 自然凝集および従 来の解析法では判別しにくいことを示唆するものである。 よって, 我々が提案する新しい解析法を用いることにより, より高精度で糖尿病患者における血小板凝集能の克進を検 出可能であることが示唆された。今後, レーザ散乱粒子計 測法を用いた血小板凝集能測定は, 我々が提案した解析法 を用いることで, 様々な疾患に臨床応用が可能であること が期待される。

\section{5. むすび}

本研究では，血小板の活性化から小凝集塊生成初期に血 小板凝集能の解析を限定することで，血小板活性化のし易 さと血小板凝集の克進度を明瞭に検知でき, 健常者に比し, 糖尿病患者における血小板凝集能の京進をより高精度に検
出できることが示された。

(平成 19 年 1 月 26 日受付, 平成 19 年 5 月 7 日再受付)

\section{文献}

(1) GV. BORN : "Aggregation of blood platelets by adenosine diphosphate and its reversal", Nature, Vol.194, pp.927-929 (1962)

(2) GV. BORN : "Observations on the change in shape of blood platelets brought about by adenosine diphosphate", J Physiol., Vol.209, No.2, pp.487-511 (1970)

(3) GV. Born and M. Hume : "Effects of the numbers and sizes of platelet aggregates on the optical density of plasma", Nature, Vol.215, No.5105, pp.1027-1029 (1967)

(4) A. Kitek and K. Breddin : "Optical density variations and microscopic observations in the evaluation of platelet shape change and microaggregate formation", Thromb Haemost., Vol.44, No.3, pp.154-158 (1980)

(5) AR. Gear and JK. Lambrecht : "Reduction in single platelets during primary and secondary aggregation", Thromb Haemost., Vol.45, No.3, p.298 (1981)

(6) MM. Frojmovic, JG. Milton, and A. Duchastel : "Microscopic measurements of platelet aggregation reveal a low ADP-dependent process distinct from turbidometrically measured aggregation", J Lab Clin Med., Vol.101, No.6, pp.964-976 (1983)

(7) NT. Thompson, MC. Scrutton, and RB. Wallis : "Particle volume changes associated with light transmittance changes in the platelet aggregometer: dependence upon aggregating agent and effectiveness of stimulus", Thromb Res., Vol.41, No.5, pp.615-626 (1986)

(8) Y. Ozaki, K. Satoh, Y. Yatomi, T. Yamamoto, Y. Shirasawa, and S. Kume : "Detection of platelet aggregates with a particle counting method using light scattering", Anal Biochem., Vol.218, No.2, pp.284-294 (1994)

(9) T. Yamamoto, Y. Egawa, Y. Shirasawa, Y. Ozaki, K. Sato, Y. Yatomi, and H. Kume : "A laser light scattering in situ system for counting aggregates in blood platelet aggregation", Meas. Sci. Technol., Vol.6, pp.174-180 (1995)

(10) G. DiMinno, MJ. Silver, AM. Cerbone, G. Riccardi, A. Rivellese, and M. Mancini : "Platelet fibrinogen binding in diabetes mellitus. Differences between binding to platelets from nonretinopathic and retinopathic diabetic patients", diabetes, Vol.35, Vol.2, pp.182-185 (1986)

(11) G. Davi, I. Catalano, M. Averna, A. Notarbartolo, A. Strano, G. Ciabattoni, and C. Patrono: "Thromboxane biosynthesis and platelet function in type II diabetes mellitus", N Engl J Med., Vol.322, No.25, pp.1769-1774 (1990)

(12) Y. Ohkubo, H. Kishikawa, E. Araki, T. Miyata, S. Isami, S. Motoyoshi, Y. Kojima, N. Furuyoshi, and M. Shichiri : "Intensive insulin therapy prevents the progression of diabetic microvascular complications in Japanese patients with non-insulin-dependent diabetes mellitus: A randomized prospective 6-year study", Diabetes Res Clin Pract., Vol.28, No.2, pp.103-117 (1995)

(13) H. Suzuki, RL. Kinlough-Rathbone, MA. Packham, K. Tanoue, H. Yamazaki, and JF. Mustard : "Immunocytochemical localization of fibrinogen on washed human platelets. Lack of requirement for fibrinogen during adenosine diphosphate-induced responses and enhanced fibrinogen binding in a medium with low calcium levels", Blood, Vol.71, No.4, pp. $850-860$ (1988)

(14) RW. Colman : "Aggregin: a platelet ADP receptor that mediates activation", FASEB J., Vol.4, No.5, pp.1425-1435 (1990)

(15) HJ. Motulsky and PA. Insel : "Adrenergic receptors in man: direct identification, physiologic regulation, and clinical alterations", N Engl J Med., Vol.307, pp.18-29 (1982)

(16) WR. Figures, LM. Scearce, Y. Wachtfogel, J. Chen, RF. Colman, and RW. Colman : "Platelet ADP receptor and alpha 2-adrenoreceptor interaction. Evidence for an ADP requirement for epinephrine-induced platelet activation and an influence of epinephrine on ADP binding", J Biol Chem., Vol.261, No.13, pp.5981-5986 (1986)

(17) Y. Miura, M. Ohnuma, MJ. Stephanie, and M. Moroi : "Cloning and Expression of the Platelet-Specific Collagen Receptor Glycoprotein VI", Thromb Res., Vol.98, No.4, pp.301-309 (2000)

(18) T. Nakano, K. Hanasaki, and H. Arita : "Possible involvement of cytoskeleton in collagen-stimulated activation of phospholipases in human 
platelets", J Biol Chem., Vol.264, No.10, pp.5400-5406 (1989)

(19) K. Fukuda, Y. Ozaki, K. Satoh, S. Kume, M. Tawata, T. Onaya, K. Sakurada, M. Seto, and Y. Sasaki : "Phosphorylation of myosin light chain in resting platelets from NIDDM patients is enhanced: correlation with spontaneous aggregation", Diabetes, Vol.46, No.3, pp.488-493 (1997)

(20) E. Iwase, M. Tawata, K. Aida, Y. Ozaki, S. Kume, K. Satoh, R. Qi, and T. Onaya : "A cross-sectional evaluation of spontaneous platelet aggregation in relation to complications in patients with type II diabetes mellitus", Metabolism, Vol.47, No.6, pp.699-705 (1998)

(21) T. Yamamoto, M. Kamei, N. Yokoi, T. Yasuhara, M. Tei, and S. Kinoshita : "Platelet aggregates in various stages of diabetic retinopathy: evaluation using the particle-counting light-scattering method", Graefes Arch Clin Exp Ophthalmol., Vol.243, No.7, pp.665-670 (2005)

(22) H. Matsuno, H. Tokuda, A. Ishisaki, Y. Zhou, Y. Kitajima, and O. Kozawa : "P2Y12 receptors play a significant role in the development of platelet microaggregation in patients with diabetes", J Clin Endocrinol Metab., Vol.90, No.2, pp.920-927 (2005)

（非会員） 1978 年 5 月 18 日生。 2002 年 3 月慶 應義塾大学理工学部物理情報工学科卒業。2004 年 3 月同大学大学院理工学研究科修士課程修 了。現在, 同大学大学院同研究科博士課程に在 籍。生体医工学, バイオイメージング, バイオ メカニクスなどの研究に従事。日本微小循環学 会, 日本バイオイメージング学会, 日本バイオ レオロジー学会各会員。
関 塚 永 - (非会員) 1951 年 11 月 23 日生。1980 年慶應

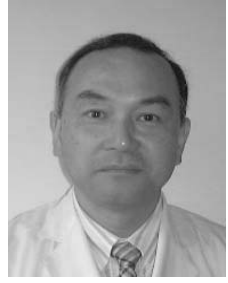

義塾大学医学部卒業。医学博士。現在, 国立病 院機構埼玉病院副院長および付属看護学校副 学校長。同臨床研究部藏器循環器室長。藏器微 小循環, 糖尿病細小血管障害, カロリー制限・ 絶食療法の生体に及ぼす影響などの研究に従 事。日本消化器病学会, 日本糖尿病学会, 日本 肝臟病学会, 日本微小循環学会, 日本バイオイ メージング学会各会員。

南 谷 晴 之 (正員) 1943 年 10 月 31 日生。1966 年 3 月慶

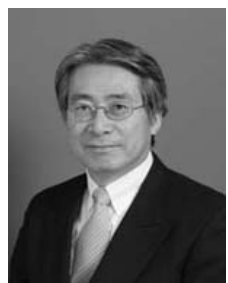
應義塾大学工学部電気工学科卒業。1971 年 3 月慶應義塾大学大学院工学研究科博士課程修 了。工学博士。現在, 慶應義塾大学理工学部物 理情報工学科教授。生体医工学, バイオイメー ジング, 生体光計測などの研究に従事。電子情 報通信学会, 計測自動制御学会, 日本生体医工 学会, 日本バイオイメージング学会, 日本微小

循環学会等各会員。 